\title{
Revolution as Redemption: Daniel Guérin, Religion and Spirituality
}

David Berry

Loughborough University, UK

The contribution of Daniel Guerin (1904-1988) to the 'rehabilitation' of anarchism in the I96os is well known, as is his commitment to anticolonialism and gay liberation. Based on biographical research on Guerin's early years examining the reasons for his 'conversion' to revolutionary politics (given his social origins in the Parisian grande bourgeoisie), this chapter asks to what extent we can say that his political commitments from I930 onwards were motivated or underlain by religious or spiritual ideas, or represented some kind of political or secular religion. Using unpublished archival sources as well as Guérin's autobiographical and fictional writings, I examine the various childhood influences on his ethical and spiritual ideas, especially his discovery as a teenager of Tolstoy and his close friendship during the I920s with the novelist François Mauriac, as evidenced in their correspondence, which makes clear the spiritual crisis Guérin struggled through as he sought to reconcile his concern with sexual liberation, his evident fideistic tendencies, and the reactionary stance of the Catholic church. Moral outrage and guilt over his own privileges led him to seek redemption through a Gandhian 'religion of service', putting himself at the service of the Revolution (with a capital R) in order to help the oppressed and exploited achieve liberation. Love ('fraternity', 'mana') was central to his thinking and to his responses to others' suffering; for him it was constitutive of what it is to be human and therefore enabled self-realisation through 'merging with the people'. This faith in Revolution is an aspect of what Gentile calls a 'religion of humanity', and of what Aron referred to as a 'secular religion' - a doctrine that promises ultimate salvation, but in this world.

How to cite this book chapter:

Berry, D. 2020. Revolution as Redemption: Daniel Guérin, Religion and Spirituality. In: Christoyannopoulos, A. and Adams, M. S. (eds.) Essays in Anarchism and Religion: Volume III. Pp. I 5 I-I 88. Stockholm: Stockholm University Press. DOI: https://doi.org/Io.I6993/bbb.e. License: CC-BY 
In short, love is the great, the solemn, I would almost say the only purpose of humanity.

- Pierre-Joseph Proudhon ${ }^{\mathrm{I}}$

If I found myself entirely absorbed in the service of the community, the reason behind it was my desire for self-realization.

- Mohandas Gandhi ${ }^{2}$

To what extent can we say that Daniel Guérin's political commitments were motivated or underlain by religious or spiritual ideas, or that they represented some kind of political or secular religion, however defined? 3 The impetus for this questioning lies in research conducted on the first three decades of Guérin's life as part of a longer biographical study, research which has thrown light on a surprising side of the young militant's ideas. ${ }^{4}$ Indeed Guérin (1904-1988) is doubtless best known to students of anarchism for his two best-selling 1965 books, Anarchism: From Theory to Practice, and the anthology No Gods, No Masters, as well as for his later promotion of a synthesis of anarchism and Marxism. ${ }^{5}$

I Pierre-Joseph Proudhon, Système des contradictions économiques. Philosophie de la misère (Paris: Garnier Frères, I850), pp. 363-64. All translations are the present author's unless stated otherwise.

2 Mohandas Gandhi, An Autobiography. The Story of my Experiments with Truth (London: Penguin, 2007), p. I 55. First published I927-29.

3 These terms first came to be widely used in the I930s - the period during which Guérin first became politically active - in analyses of Bolshevism, fascism and nazism, and saw aspects of some ideologies and political movements as replacing traditional religions. The concepts are still contested. See Emilio Gentile, Politics as Religion (Woodstock: Princeton University Press, 2006).

4 Other aspects of this period in Guérin's life have been examined in greater detail in David Berry, 'Metamorphosis: The Making of Daniel Guérin, I904-I930', Modern \& Contemporary France vol. 22, no. 3 (August 2OI4), 32I-42; and Berry, 'From son of the bourgeoisie to servant of the Revolution: The roots of Daniel Guérin's revolutionary socialism', Moving the Social - Journal of Social History and the History of Social Movements vol. 5I (20I4), pp. 283-3II.

5 L'Anarchisme, de la doctrine à la pratique (Paris: Gallimard, Ist ed. I965); translated by Mary Klopper as Anarchism: From Theory to Practice (New York \& London: Monthly Review Press, I970); Introduction by Noam Chomsky. Ni dieu ni maître, anthologie de l'anarchisme (Lausanne: La Cité-Lausanne, Ist ed. I965); translated by Paul Sharkey as No Gods, No Masters: An Anthology of Anarchism (Edinburgh: AK Press, I998), 
(It is perhaps worth noting in passing that despite the strong tradition of anticlericalism in French anarchism, and the French left generally, Guérin did not include anything concerning religion in his anthology beyond a passing mention of 'the theological ramblings' of primitive human societies in an extract from Bakunin's God and the State. $\left.{ }^{6}\right)$ Marxists, especially Trotskyists, admire his Fascism and Big Business and his Class Struggles under the First Republic. ${ }^{7}$ Others will be more familiar with his campaigns for the liberation of the French colonies from the I930s onwards, or for homosexual emancipation in the I960s and against militarism in the 70 s and 8os. The purpose of this paper, however, is to focus on one particular aspect of what he described as 'the unorthodox paths by which a son of the bourgeoisie sought to merge with the people and ultimately to put himself at the service of the Revolution's: what experiences and intellectual influences of a spiritual nature led him to reject bourgeois society in favour of other values-in the process undergoing a series of 'conversions'. 9 Prolific though he was, Guérin never devoted any of his writings to religion or spirituality as such, and this will the-

2 vols. See also David Berry, 'The Search for a Libertarian Communism: Daniel Guérin and the 'synthesis' of Marxism and Anarchism', in Libertarian Socialism: Politics in Black and Red ed. by Alex Prichard, Ruth Kinna, Saku Pinta \& David Berry (Oakland, CA: PM Press, 2017), pp. I87-209. For a comprehensive primary and secondary bibliography, see the website of the Association des Amis de Daniel Guérin (http:// www.danielguerin.info).

${ }^{6}$ Ni dieu ni maître (Paris: La Découverte/Syros, I999 edition), p. I7I.

7 Fascisme et grand capital (Paris: Gallimard, Ist ed. I936); translated by Frances and Mason Merrill as Fascism and Big Business (New York: Pioneer Press, Ist ed. I939), introduced by Dwight Macdonald. La lutte de classes sous la Première République, I793-I797 [Class Struggle under the First Republic] (Paris: Gallimard, I946; revised edition I968), 2 vols., has never been translated in full.

${ }^{8}$ Daniel Guérin, Autobiographie. D’une dissidence sexuelle au socialisme (Paris: Belfond, I972), p. 9.

9 On this notion of 'conversions' and the subsequent production of new life-narratives by the autobiographical subject, see Todd Weir, 'Between Colonial Violence and Socialist Worldview: The Conversions of Ernst Däumig', German History 28: 2 (2010), I43-66. See also D. Bruce Hindmarsh, The Evangelical Conversion Narrative: Spiritual Autobiography in Early Modern England (Oxford: OUP, 2007). 
refore be a biographical study based primarily on a close reading of his several autobiographical texts, his fictional works and his private correspondence, as well as other unpublished papers. In the process, I hope to clarify the nature and roots of his later political positions and more specifically their ethical, philosophical or spiritual foundations. For as Orwell said of the examination of his own formative influences:

I give all this background information because I do not think one can assess a writer's motives without knowing something of his early development. His subject matter will be determined by the age he lives in - at least this is true in tumultuous, revolutionary ages like our own - but before he ever begins to write he will have acquired an emotional attitude from which he will never completely escape. ${ }^{\text {Io }}$

\section{Family background}

To a large extent, the story of Guérin's adoption of the cause of the oppressed was to be coterminous with his growing determination to reject all ties with his own class, the grande bourgeoisie. Nevertheless, it becomes clear on reading Guérin's autobiographies and from interviews that Guérin's politics and more general outlook on life owed much to the influence of his branch of the family: humanist, liberal and cultured, both his parents had been 'passionately pro-Dreyfus' - in other words, republican, antinationalist and antiracist. ${ }^{\text {II }}$ Daniel's father, Marcel Guérin, had in his youth served at Toynbee Hall in Whitechapel-the original university 'settlement house' of the so-called 'settlement movement', which welcomed graduates who volunteered to teach and to do social work in poor urban areas. Marcel published a report on his visit in the newsletter of the Musée Social: Daniel's personal papers contain a copy bearing the handwritten dedication: 'To my dear son Daniel to give him a

ro George Orwell, 'Why I Write' ( I 946), in The Collected Essays, Journalism and Letters of George Orwell, vol. I- An Age Like This 1945-1950 (London: Penguin, I970); also available at: http://orwell.ru/library/ essays/wiw/english/e_wiw.

I Guérin, Autobiographie, pp. Iо \& I6. 
taste for social questions.' ${ }^{\text {I2 }}$ This exposure to the situation of the working class in London's East End had prompted Marcel to read, amongst others, Marx, Proudhon and Kropotkin, and especially Tolstoy. The Tolstoyan influence was strong on the mother's side of the family too: a 'consummate polyglot', Daniel's great-grandmother had translated two of Tolstoy's novels into French. ${ }^{\mathrm{I3}}$

These Tolstoyan tendencies were evident at the time of the Great War, when the young Daniel's feelings of incomprehension and revulsion at the killing and the suffering were shared by his 'antimilitarist' father: 'the absurd slaughter disgusted him to the point of nausea.' ${ }^{\text {I4 }}$ Invited to participate in some propaganda work designed to boost national morale, Marcel Guérin refused outright, writing afterwards to a friend: 'I confess I suffered an attack of anarchism. It's my old Jacobin blood boiling from time to time.' ${ }^{\text {I5 }}$ But these pacifist leanings would resurface periodically, with news of further pointless mass slaughters provoking in him, in his own words, 'upsurges of antimilitarism and of anarchism'. ${ }^{16}$

Guérin's mother and grandmother signed up with the Red Cross and served as nurses. Accompanying his mother, Daniel witnessed with his own eyes some of the horrific injuries of the soldiers - including the last moments of a German prisoner of war who became for him no longer an 'Alboche' (an older form of the pejorative term 'Boche'), but 'just a man, a man who was dying in the convulsions of tetanus'. Like many others, Daniel also 'adopted' a soldier with whom he corresponded and to whom he sent parcels, meeting him when he came home on leave. His

¿2 Bulletin mensuel du Musée Social I2, série B (30 August I897). I am grateful to Anne Guérin for giving me access to this and other papers of her father's. See also Janet R. Horne, A Social Laboratory for Modern France: The Musée Social and the Rise of the Welfare State (Durham, NC: Duke University Press, 2002).

${ }^{13}$ Guérin, Autobiographie, p. I5. On 'Tolstoyism' in France, see F.W.J. Hemmings, The Russian Novel in France, I 884-I9 I4 (Oxford University Press, I950).

${ }^{14}$ Guérin, Autobiographie, pp. $68 \& 63$.

Is Quoted in Guérin, Autobiographie, p. 64.

I6 Quoted in Guérin, Autobiographie, p. 64. 
guilty feelings grew at leading 'the life of a prince, far too pleasant, too easy, too protected, too spoiled'. ${ }^{17}$

Towards the end of the Great War, the fourteen year old Daniel dedicated a poem to his father, 'Pendant qu'ils se tuaient...' ['While they were killing each other...'], which evoked a feeling of profound incomprehension in the face of the serene calm and beauty of the scenes of nature and of everyday life around him, 'When all the universe resounds with suffering, When man, stupefied, loses hope.' ${ }^{\text {I8 }}$ Many years later, reading his father's correspondence from this period would make Daniel realize how much his own attitudes owed to 'this simmering anarcho-pacifism', ${ }^{19}$ and in the I970s he would be a prominent figure in antimilitarist campaigns. 'At the age of 80 ', he would write in an introduction to the memoirs of the anti-war syndicalist François Mayoux, 'I can say that $[. .$.$] the hatred of war, the struggle against war have been the$ visceral passion of my own life.'2o

\section{On the Church and reading Tolstoy}

Guérin was raised in the Catholic Church, albeit not particularly devoutly. In his autobiography he refers to his parents' 'vague Jansenism, an attitude which was more moral than religious' ${ }^{21}$, and many years later in an interview with the philosopher and journalist Christian Chabanis he would comment that his grandfather had been an atheist, his father had been 'completely irreligious', and although his mother had taken him to mass on Sundays it was largely 'a society religion'. ${ }^{22}$ Be that as it may, in I9I 5 Daniel took his first communion, and the following year he

\footnotetext{
${ }_{17}$ Guérin, Autobiographie, p. 62.

¿8 Guérin, Le Livre de la dix-huitième année (Paris: Albin Michel, I922), pp. 56-58.

19 Guérin, Autobiographie, p. 64.

${ }^{2}$ Marie \& François Mayoux, Instituteurs pacifistes et syndicalistes. Mémoires de F. Mayoux (Chamalières: Editions Canope, I992), p. I2.

${ }^{21}$ Guérin, Autobiographie, p. 73. Jansenism emphasised humanity's sinfulness and the necessity of divine grace.

${ }^{22}$ Interview in Christian Chabanis, Dieu existe-t-il? Non (Paris: Fayard, I973), pp. 222-3. A companion volume - Dieu existe? Oui - was published in 1979.
} 
was sent to a Catholic school, the Ecole Bossuet, though whilst still taking classes at lycée (that is to say that the priests took their wards to lycée in the morning and brought them back in the afternoon before delivering them to their families at seven in the evening after religious instruction). ${ }^{23}$ The repeated religious exercises, the sumptuous ceremonies, the candles and the incense induced in Guérin an 'attack of mysticism' and he experienced a taste, he claimed, of 'what believers call the spiritual life'. ${ }^{24}$ The feeling and the certainty would not, however, last for long: 'I was not really gifted for the supernatural. ${ }^{25}$ Indeed, so negative was the impression made on him by the authoritarianism and the hypocrisy of the priests themselves at the Ecole Bossuet that the experience seems to have contributed to his loss of faith and the beginnings of his lifelong anticlericalism.

The real 'crisis', as the young Guérin experienced it, would occur soon afterwards. Whilst turning him away from institutionalised religion in some respects, the Ecole Bossuet had nevertheless instilled in him 'something of a tendency towards belief'. ${ }^{26}$ In the interview with Chabanis about the existence of god he would talk about the 'passionate dialogues' he held with Jesus during his year at the school: 'For me, Jesus was a human incarnation, a human being whom I adored and to whom I spoke.' ${ }^{27}$ But at the age of fourteen, Guérin definitively lost not only his belief in the Catholic Church but his faith in Christianity itself on reading his mother's copy of Tolstoy's diaries:

At first, this book inspired no mistrust on my part, as it was the work of a Christian, of a believer in search of true Christianity, the work what's more of a social apostle of whose teachings my father had, at one time in his life, been a follower. And yet this book spoke a language which I had never before heard. It cast doubt on the absolute truth of the myths and beliefs brought forth by human societies of the most diverse epochs and origins. [...] Tolstoy brought into question my entire upbringing. Evil arises, according

\footnotetext{
${ }_{23}$ Guérin, Autobiographie, p. 64.

${ }_{24}$ Guérin, Autobiographie, p. 72.

25 Guérin, Autobiographie, p. 72.

26 Chabanis, Dieu existe-t-il? Non, p. 22 I.

27 Chabanis, Dieu existe-t-il? Non, p. 223.
} 
to him, from the fact that I attached too little importance to reason. It is the fruit of the false education which I had been given since my childhood. [...] The first thing I had to achieve was my religious emancipation. [...] I gave myself without reserve to Tolstoy. ${ }^{28}$

But having accepted Tolstoy's critique of the Church and its teachings, Guérin found that his faith as a whole was undermined. His response was to throw himself into the study of theology, philosophy and even the physiology of the brain. His mother, in whom he confided regarding this spiritual crisis, promptly arranged for him to meet the eminent priest and historian of the Church's teachings, Monseigneur Pierre Batiffol. He and Guérin had interminable philosophical discussions, but these changed nothing largely because, as Guérin writes, he came to the conclusion that 'this overly philosophical bishop had no more faith than I did': 'His arguments were so Cartesian, so scientific, so materialist, that he actually confirmed me in the decision I had taken to abandon my religious faith.' ${ }^{29}$

Guérin continued nevertheless to read Tolstoy, and his novel Resurrection made a particular impression - 'perhaps because of the passionate attack on an iniquitous society', he comments in his autobiography. ${ }^{\circ}$ One cannot help however but be struck by certain parallels with Guérin's own life: Resurrection recounts the moral and spiritual crisis of a cosseted and self-centred young aristocrat caused by his discovery of the suffering of the poor, and his subsequent determination to reject his own class and the artificiality of society in order to help the oppressed, no matter the cost to himself...

\section{The Pagan and the Catholic}

In 1922, Guérin had managed to pluck up the courage to take a collection of his poems written since I9 8 , Le Livre de la DixHuitième Année, to a publisher. Strongly influenced by Baudelaire amongst others, they bore witness to the depth of Guérin's emo-

\footnotetext{
${ }^{28}$ Guérin, Autobiographie, pp. 80-I.

29 Guérin, Autobiographie, pp. 8I-2; Chabanis, Dieu existe-t-il? Non, p. 222.

$3 \circ$ Guérin, Autobiographie, p. 94-5.
} 
tional life and the anguish caused by the conflict between the yearning for platonic love and that for sensuality-'the tyranny of the organs' as Proudhon put it ${ }^{3{ }^{3}}$. Guérin was delighted to receive encouraging letters from a number of prominent literary figures, including Maurice Barrès and François Mauriac. Barrès was a novelist, journalist and right-wing politician who had been one of the leading figures in the anti-Dreyfus camp. He held complex and contradictory views with regard to both politics and religious belief; his novels were extremely influential on younger generations of writers in the inter-war years, including Mauriac, and Guérin was also an admirer. ${ }^{32}$ Guérin first met Mauriac - who would be made a member of the Académie Française in 1933, but was already a successful novelist by this time - the following year, and the two got on immediately. Mauriac was particularly attracted to the rebellious spirit and demanding intelligence of this 'young pagan' ${ }^{33}$ In him, Mauriac recognised 'at once his double and his opposite at the same age: a young, marginal and rebellious bourgeois, but one who was much more radical and emancipated in his way of living, of being and of thinking. ${ }^{34}$

At first, Mauriac took seriously his role as guardian or mentor, responding to Guérin's assertion that he needed Mauriac: 'It is true that I can fulfil for you what the adolescent Barrès wished for: 'a friend who would be an older version of myself", he wrote. 'I know you to the extent that I know myself and I hear what you do not say. ${ }^{35}$ Yet interestingly, in the same letter, Mauriac

${ }^{31}$ Proudhon, Système des contradictions économiques, p. 363.

32 See The New Oxford Companion to Literature in French, ed. by Peter France (Oxford: Oxford University Press: I995) and R. Gibson, 'The First World War and the Literary Consciousness', in French Literature and its Background, ed. by John Cruickshank (Oxford: Oxford University Press, I970), vol. 6, pp. 56-72.

33 François Mauriac, letter to his wife, quoted in Jean-Luc Barré, François Mauriac: Biographie intime, vol.r: I885-I940 (Paris: Fayard, 2009), p. 380 .

34 Barré, François Mauriac, p. 380.

35 François Mauriac, letter to Daniel Guérin, I9 November I924, in François Mauriac, Nouvelles lettres d'une vie (1906-70), ed. by Caroline Mauriac (Paris: Bernard Grasset, I989), p. 99; also quoted in Barré, François Mauriac, p. $38 \mathrm{I}$. 
also contrasted his own adolescent rejection of all constraint with what he perceived to be Guérin's nature, comparing him to the quasi-mystical, nationalist writer Ernest Psichari, who rejected what he saw as the decadence of Belle Epoque society and had converted to Catholicism in I9I3:

And you, on the contrary, my dear child of the Left [...], you are also, without realising it, a little brother to Psichari, made to obey and to command, infused with the passionate desire to enter a religious order. ${ }^{36}$

Guérin quickly became the only person to whom Mauriac felt able to confess his deepest and most troubling feelings, and the profound emotional and spiritual crisis through which Mauriac was going at the time led in a short time to a reversal of roles between the two men. ${ }^{37}$ The following year, Guérin started what was to be a long correspondence with Mauriac. He began it with a nostalgic letter about his loss of faith: 'An unconsolable mystic, that's what I am, you know. And yet more distant from God than ever'; 'Believers are happier than we are'. ${ }^{38}$ The believer Mauriac, in reply, attempted to console him and encourage faith and moral steadfastness.

'...But something is always lacking in our hearts...', it is you who wrote this, my dear friend-and that is a humble reason to fall to our knees-a very humble reason, and yet one which remains for me, after so many years of doubt, anguish and desolation, the most effective. That hunger for a joy without shadow, that hunger for God survives within me despite all the disappointments, all the

${ }^{36}$ Ibid; emphasis in the original. On Psichari, see France, The New Oxford Companion to Literature in French and Gibson, 'The First World War and the Literary Consciousness'.

37 It would be thanks to information divulged by Guérin in an interview many years later, that it would first become widely known that Mauriac had enjoyed homosexual relationships. See 'Entretien avec Daniel Guérin', in Paris Gay I925, ed. by Gilles Barbedette and Michel Carassou (Paris: Presses de la Renaissance, I98I), pp. 43-55.

${ }^{38}$ Undated letter to F. Mauriac [I924], Bibliothèque littéraire Jacques Doucet, Ms4025I; Letter of 25 April I924, in François Mauriac, Nouvelles lettres, pp. 92-93. 
errors, and, as I advance towards the end, it is in that hunger, that spiritual instinct, which I trust. ${ }^{39}$

But how, Guérin objected, can one practise a religion which claims to be in the service of the poor and yet which for centuries has been an instrument of oppression in the hands of the powerful? What is more, he argued, it is religion which sullies physical love, 'the healthiest and most natural act', by imprinting upon it 'the stigmata of Sin.' ${ }^{\circ}$ Mauriac's response was to insist that 'it is not religion which attaches something tragic to the flesh, this tragic aspect is there in reality, and one has to be blind not to see it'; and a part of Guérin seems to have shared this feeling that the 'frenzy of the baser instincts' undermined the 'purity' and 'nobility' of which humankind is capable. ${ }^{{ }^{\mathrm{I}}}$ This conversation between the two would be repeated in one form or another for some time and would never be resolved. For Guérin, Mauriac 'needed to believe, above all, in order to escape from temptation'; he himself, on the other hand, needed to overcome 'the strange resistance which, since puberty, has prevented me, at every attempt, from taking the plunge.' With hindsight, he concluded that he and Mauriac 'did not speak the same language, we have completely opposite problems to solve.' ${ }^{22}$ Thirty years later - shortly before coming out - Guérin would argue strongly that sexual liberation was but one aspect of the quest for human freedom in general: 'If we wish to make free men, we must disalienate the Flesh, not repress it.' ${ }^{3}$ So despite Guérin's fideistic tendencies - what Le Bon saw as an instinctual 'need to submit oneself to a divine, political or social faith' ${ }^{44}$ - he rejected the Catholic religion, at least, because of its hostility to sex and in particular to homosexuality.

\footnotetext{
39 F. Mauriac, letter to D. Guérin of 25 April I924, in Nouvelles lettres d'une vie.

$4 \circ$ Guérin, Autobiographie, p. I39.

${ }^{41}$ Letter of 2 March I926, in François Mauriac, Nouvelles lettres, p. Io6.

${ }^{22}$ Guérin, Autobiographie, p. 139.

43 Guérin, Shakespeare et Gide en correctionnelle? Essai (Paris: Editions du Scorpion, I959), p. Io.

${ }_{44}$ Gustave Le Bon, Psychologie du socialisme (Paris, I920), quoted in Gentile, Politics as Religion, p. 6.
} 
Towards the end of 1924 , during his military service and after being tormented by his confused and confusing emotional and sexual needs for several years, Guérin finally found happiness in an affectionate (albeit sexually unconsummated) relationship with a sergeant from a different unit: 'So, I was no longer a monster, a pariah. I was receiving my share of joy, like every living being. [...] In Strasbourg, I was beginning to live.'45 Nevertheless, he still struggled with feelings of guilt. A rather allusive letter to Mauriac provoked a fervent reply from the Catholic urging him to resist the temptations of the flesh created by his 'appetite for tenderness', so that he might 'live'. Looking back, Guérin comments: 'Yes, I certainly wanted to live. But in order to live at last, I had first to stop resisting the call of my very nature, and cease listening to the paralysing interdict imposed by religion. ${ }^{46}$

\section{Point of departure: the divine need to love}

In the autumn of I925, two texts appeared which Guérin had written during his military service. The first, entitled 'Point de Départ', was published in the literary magazine, the Revue Hebdomadaire, with an introduction by Mauriac (who had advised Guérin on a first draft). It is in some ways characteristic of the kind of 'generationalist' writing - to use Wohl's term ${ }^{47}$ - which appeared in this period, and the humanist's malaise to which it gives voice chimes with that of other intellectuals who had lived through

45 Guérin, Autobiographie, p. I 54.

${ }_{46}$ Guérin, Autobiographie, p. I 54.

47 See Robert Wohl, The Generation of I9I4 (London: Weidenfeld and Nicolson, I980); Gibson, 'The First World War and the Literary Consciousness'; Mary Jean Green, 'Visions of Death and Dissolution', in A New History of French Literature, ed. by Denis Hollier (Cambridge MA: Harvard University Press, I989), pp. 850-5. The notion of 'generation' is of course not unproblematic, as Nora comments in the first sentence of a discussion of the history of the concept: 'It is difficult to think of a notion that has become more commonplace yet at the same time more opaque than that of 'generation'.' 'Generation' in Pierre Nora (ed.), Realms of Memory. The Construction of the French Past (New York: Columbia University Press, I996), pp. 499-53I. 
the Great War and its aftermath. ${ }^{48}$ The tone of bewilderment and disillusion is reminiscent of Paul Valéry's I9I9 essay, 'La Crise de l'esprit' ['The Crisis of the Spirit'], which conjures the image of 'an intellectual Hamlet meditating on the life and the death of the verities'49; or of André Malraux's La Tentation de l'Occident [The Temptation of the West] (I926), which concludes: 'There are no ideals to which we can sacrifice ourselves, for we know all their lies, we who do not know what is truth.' ${ }^{50}$ Underlining the extraordinary situation of his own generation (who unlike Wohl's 'generation of I9I4' had been too young to experience the war directly, but grew up with its consequences), Guérin emphasises the significance of the rupture represented by the Great War..$^{5 \mathrm{I}} \mathrm{He}$ also attacks not only the complacency of pre-war Europe's belief in the solidity of its 'old idols' - its political institutions, its colonial conquests and its liberal economy - but also the responsibility of earlier generations for the catastrophe of I9I4. Writing in 1938 , the Italian philosopher Adriano Tilgher would use the concept of the numinous to interpret the various secular religions which appeared after the Great War and 'through which Western Civilization attempted to fill the vacuum left in the spirit by the decine of Christianity'. ${ }^{22}$ Guérin drew on the Indian writer and philosopher Rabindranath Tagore to question the value of the merely material advantages of modern capitalism: 'But what of the mind, what of the need for love?' With the decline of religious belief, he asks, 'what nourishment is left to us? In the depths of the eyes of each of our contemporaries, we can read utter dissatisfaction, thirst,

${ }^{48}$ See Gibson, 'The First World War and the Literary Consciousness', pp. 56-72.

49 PaulValéry, 'La Crise de l'esprit', first published in Variété(Paris: Gallimard, I924), http://wikilivres.ca/wiki/La_Crise_de_1\%E2\% $80 \%$ 99esprit

5o Quoted in Gibson, 'The First World War and the Literary Consciousness', p. 66.

${ }_{51}$ On the generation of intellectuals born in 1905 , see Jean-François Sirinelli, Génération intellectuelle: khagneux et normaliens dans l'entredeux-guerres (Paris: Fayard, I988).

${ }_{52}$ Quoted in Gentile, Politics as Religion, p. Io. Gentile (p.I) defines secular religions as ideologies and ideals that intended to replace traditional metaphysical religion with new humanist concepts that created a cult of humanity, history, nation and society.' 
emptiness. ${ }^{93}$ And yet criticism of Guérin's fatalism by Mauriac, and the advice not to simply curse life but to illuminate it and strive to change it had an effect: 'This lesson, which at the age of 2 I I had been unable to draw by myself, did not fall on deaf ears.' ${ }^{54}$

\section{The Magic of Good Friday}

The second text to appear in 1925 was Guérin's first novel, L'Enchantement du Vendredi Saint [The Magic of Good Friday], whose main purpose he described as being to 'come to terms, this time through the transparent veil of a fiction, with the dramas of tenderness and of unsatisfied desire which had poisoned my youth.' ${ }^{5}$ But there is an evident spiritual theme in the novel too. The story's central character Armand is tormented by the conflict between reason, the passions and 'the divine need to love'. ${ }^{56}$ At a moment of crisis in the story, he turns to the Jansenist philosopher Blaise Pascal, and reads:

What is it then that this desire and this inability proclaim to us, but that there was once in man a true happiness of which there now remain to him only the mark and empty trace, which he in vain tries to fill from all his surroundings, seeking from things absent the help he does not obtain in things present? But these are all inadequate, because the infinite abyss can only be filled by an infinite and immutable object, that is to say, only by God Himself. ${ }^{57}$

'Such words', Armand notes, 'are enough to turn a man's life upside down.' Soon after, he attends a performance of Wagner's opera Parsifal, which, despite its Christian symbolism, has at its heart a number of Buddhist ideas (a result of Wagner's reading of Schopenhauer): the 'pain of untamed desire', freedom through self-abnegation, and enlightenment through self-denying

\footnotetext{
53 Guérin, 'Point de départ', La Revue hebdomadaire, 43 (24 October I925), 457-68 (introduction by Mauriac pp. 457-58); extracts also quoted in Guérin, Autobiographie, pp. I 56-9.

54 Guérin, Autobiographie, p. I60.

55 Guérin, Autobiographie, p. I60; L'Enchantement du Vendredi Saint (Paris: Albin Michel, I925).

${ }^{56}$ Guérin, L'Enchantement, p. 47.

57 Blaise Pascal, Pensées (New York: E. P. Dutton \& Co., Inc., I958), no. 425.
} 
compassion and service. The title of Guérin's novel is a reference to the 'Karfreitagszauber', the 'magic of Good Friday' which, in the climactic scene in the final act of Parsifal, renews the world and redeems humankind, now freed from its burden of sin. Whilst still resistant to the Church's theological dogmas (despite his best efforts to rediscover an orthodox faith), Armand had nevertheless found a kind of grace and a way forward.

\section{Unknown lands: the road to Damascus}

In 1927 Guérin would embark on a life-changing episode when he was offered the job of running the Syrian-Lebanese branch of the Agence Générale de Librairie, a subsidiary of Hachette, the family business. As Mauriac wrote to him on hearing the news, it would be exactly the kind of 'break' in Guérin's life that he needed.$^{8}$ For Guérin, tiring of a life in which 'physical satiation' - thanks to a string of sexual partners - had begun to take too large a place, this opportunity was to be a welcome 'leap into the unknown':

This journey was going to take me much further than the Levant. Although I did not know it at the time, I was leaving behind me not just the bosom of my family, but other shores as well: bourgeois society and Europe. I was setting a course for a succession of unknown lands: the Orient, Islam, Asia, decolonisation and, beyond, socialism. ${ }^{59}$

During his time in Beirut, the person who most profoundly affected Guérin was Louis Massignon, a professor at the Collège de France (the most prestigious academic institution in France) and an expert on Islam and sufism. Described by Guérin as a mystic, Massignon had come to his 'fervent' Roman Catholicism through his researches into Arab mystics, having written a thesis on sufism:

Whilst, objectively, his project was decolonisation, as one would say nowadays, his subjective purpose was to build a bridge between

$5^{8}$ Letter of 9 September 1927, in Mauriac, Nouvelles lettres d'une vie, p. I I6.

59 Guérin, Autobiographie, pp. I78 \& 183. 
Christianity and Islam. [...] In his ardent youth, in Morocco, he had become enamoured of the muslims. ${ }^{60}$

Indeed, Guérin's representation of his life in the Levant was of a contrast between these two different worlds between which he slipped 'without transition'. He had one foot in Beirut, leading the usual, 'worthless' life of a privileged member of the French expatriate community; the other foot was in Damascus, 'at the heart of Islam', a life which included on one occasion, attendance at an all night ceremony of the sufi Aissawa sect, with its ecstatic rhythms and mystic whirling dervishes. ${ }^{61}$ Guérin became more and more attracted to Islam, reading the Koran with great diligence and listening enthralled to descriptions of Mecca and tales of the English Arabist and muslim convert St. John Philby, recounted by the French consul in Saudi Arabia. 'Islam is more than a religion: it is half of the universe', he wrote to his father. And in his autobiography he remarked: 'I had a weakness for this religion without priests - just as, a little later, I would be attracted to Buddhism, a religion without gods. ${ }^{62}$ Around the same time, according to a remark made by Mauriac in a letter to Guérin, the latter had also become interested in Jacques Maritain, the philosopher who was moved to convert to Catholicism because of his disenchantment with 'scientism' and who would publish Primauté du spirituel [The Superiority of the Spiritual] in 1927 , before going on in later years to formulate a Christian humanism not dissimilar to Emmanuel Mounier's 'personalism'. ${ }^{63}$

A visit from Guérin's father was the occasion for a trip round Lebanon, Syria and Palestine. Guérin's impressions of Jerusalem are interesting, initial disappointment being effaced by 'the pure antinomic jewels of two arts and two beliefs: the

${ }^{60}$ Guérin, Autobiographie, p. I9I; Guérin, Ci-git le colonialisme (Paris: Mouton la Haye, I973), p. I I.

61 Guérin, Autobiographie, p. 196.

${ }^{62}$ Guérin, Autobiographie, p. I99.

${ }_{63}$ Letter of 2 March I926, in Mauriac, Nouvelles lettres d'une vie, p. I05. See Anthony Levi, 'Jacques Maritain' and François Nectoux, 'Emmanuel Mounier', in Encylopedia of Modern French Thought ed. by Christopher John Murray (New York \& London: Fitzroy Dearborn, 2004), pp. 458-60 \& 490-I. 
Church of the Holy Sepulchre, the Mosque of Omar. Which to prefer? Christianity? Islam?' ${ }^{4} 4$ These words would seem to suggest more than issues of aesthetic and architectural taste. One is reminded of comments made by the novelist cum travel writer Pierre Loti at the end of his account of a journey to the ruined temples of Angkor in Cambodia-a book we know Guérin read and enjoyed:

So many places of intense adoration which I have come across on my path and which all correspond to a particular form of human anguish, so many pagodas, so many mosques, so many cathedrals, where the same prayer rises from the most diverse of souls! ${ }^{65}$

Guérin spent the early summer of 1928 editing and to some extent researching and writing the Guide bleu for Syria (Blue Guides being the tourist guidebooks published by Hachette since the mid-nineteenth century). This was an onerous task, but an enlightening and fulfilling one. It led him to study, amongst many other sources on the region's ancient history, art and religion, Frazer's The Golden Bough - first published in 1890 and the first comparative study of religions and myths from an anthropological point of view - and Les Mystères païens et le Mystère chrétien [The Pagan Mysteries and the Christian Mystery] (1919) by Alfred Loisy - a Catholic theologian and a professor at the Collège de France who was a modernist (in Catholic terms) and was excommunicated in 1908: 'It was the history of religions which, in that period, most excited my irreligious curiosity. ${ }^{66}$

\section{A value to replace the flesh}

Something else on which Guérin worked hard in Beirut was a second novel, La Vie selon la chair, which was finally published at the beginning of $1929 .{ }^{67}$ The title of the book - 'Life according to the flesh' - is a biblical reference: 'For if ye live after the flesh, ye shall die: but if ye through the Spirit do mortify the deeds of

\footnotetext{
${ }^{64}$ Guérin, Autobiographie, p. 200.

${ }_{65}$ Pierre Loti, Un Pèlerin d'Angkor (Paris: Calmann-Lévy, I9 I 2), pp. 228-9.

${ }^{66}$ Guérin, Autobiographie, p. 202.

${ }^{67}$ La Vie selon la chair (Paris: Albin Michel, I929).
} 
the body, ye shall live' (Romans 8:13, King James Version). In it, Guérin gave vent to what he called his 'carnal tempests'. ${ }^{68} \mathrm{~A}$ psychological novel, it follows the intertwined emotional lives of four characters. A number of themes are developed through the novel: the emotional and sexual anxieties of puberty, seen especially through the homosexual Hubert's growing awareness of his own 'singularity'; feelings of exclusion from a happiness shared by others; innocence lost and the guilt caused by the conflict between sensual desire and the young mens' moral and religious education; 'nausea' in the face of the 'void', the meaninglessness of existence, and the ways in which different characters try to disguise this reality (amoral indulgence in sensual pleasures, meaningless but socially approved routines...); the realisation that, despite our belief in free will, our lives are largely out of our control; and the impossibility of ever really understanding or communicating with others: 'Humankind [...] seemed like a bizarre ensemble of incomplete beings, of ambiguous individuals incomprehensible to themselves.' ${ }^{69}$

The novel's publication caused something of a brouhaha at home. This is not surprising, given the fairly grim picture the novel paints of four lost souls struggling to find happiness in a decadent, cynical, meaningless and sexually promiscuous society. It is also explicit for its time (although the treatment of homosexuality is relatively muted). Guérin's family was horrified. Mauriac, in whose novels the bestiality of sex is a recurrent theme, wrote to his young confidant: 'Life according to the flesh - life according to the spirit: one has to choose. ${ }^{70}$ And yet in a sense the novel is in fact extremely moral. A recurrent theme is the characters' constant attempts to find meaning and a new direction in life, the need to make choices about what course to follow, the need in fact for self-discipline: the end of the story inconclusively leaves the three main characters on the threshold of new departures, searching for 'a value able to replace the flesh. ${ }^{71}$

\footnotetext{
${ }^{68}$ Guérin, Autobiographie, p. 2 10.

69 Guérin, La Vie selon la chair, p. 208.

${ }^{70}$ Letter quoted in Guérin, Autobiographie, p. 2 I I.

${ }^{71}$ Guérin, La Vie selon la chair, p. 279.
} 
Guérin was deeply hurt by what seemed to him to be savage and unfair attacks on the novel, and the experience led him to want to break with his family and, he added, 'with myself. ${ }^{72}$ Combined with his ever growing taste for exploring Africa and Asia, this rejection also helped alienate him from France. Indeed Guérin's preferred reading in this period concerned the history of sub-Saharan Africa and Asia, as well as books on the Buddha - whose teachings fascinated him by virtue of their focus on 'the extinction of identity in Nirvana, beatitude through deliverance from the passions'. ${ }^{73}$ He now proposed to devote a three month retreat in the Far East to studying the political, economic and social questions which he had not yet been able to examine in any depth. He left again for Marseille and, on 23 December I929, without notifying his parents, set sail for the Far East aboard the cargo boat, Bangkok - which, ironically, was carrying munitions for the French expeditionary forces in the colonies in Indochina.

\section{On a slow boat to Indochina}

The Bangkok was a freighter, not a passenger-ship, and he was given 'a minuscule cabin, which was very uncomfortable, but for me heavenly'. ${ }^{74}$ Like a monk in his cell, he devoted himself to the intense, solitary study of a small library of books on Marxism, syndicalism, anarchism, colonialism and pacifism, but also of Asian religions, reading and re-reading them, taking reams of notes, and scribbling approving or critical comments on them:

Why on earth had I taken Marx's Capital, Kautsky's The Social Revolution and Socialist Programme, La révolution défigurée by Trotsky, Les Réflexions sur la violence by Georges Sorel, Gandhi's autobiography, and books about Proudhon, Jaurès, Lenin, India and China, on American imperialism, on Soviet Russia, labourism and syndicalism? Today I struggle in vain to recollect the origin of such a sudden and multifarious curiosity. 75

${ }^{72}$ Guérin, Autobiographie, p. 2 I 2.

73 Guérin, Autobiographie, pp. 2I3-I4.

74 Guérin, Autobiographie, p. 217.

75 Guérin, Autobiographie, p. 218. Guérin's reading notes are in the IISH, Amsterdam, Daniel Guérin Papers, Box I, Folder 62. Subsequent 
The effort exhausted him:

I was banging my head against a certain number of walls. My approaches towards socialism were littered with stumbling blocks and dilemmas. Socialism from above (Leninism) or from below (revolutionary syndicalism)? Marxist class struggle or Tolstoyan 'love' and Gandhist non-violence? For or against Stalin's Russia? For or against the Communist Party? For or against anarchism? The tension nearly made my head explode. ${ }^{76}$

An examination of Guérin's notes from this reading provides us with some insights into his political and ethical thinking at this point in his life, shortly before his experiences in Indochina would trigger a radical change in his life. The first thing to note is that Guérin's retrospective description of this episode as representing his 'apprenticeship in Marxism' seems misleading, or at least too simple. ${ }^{77}$ I have analysed his political views at this point elsewhere, but with regard to the focus of the present paper, a number of things are striking. ${ }^{78}$

\section{Comradeship and moral rectitude}

Firstly, there is a strong and repeated emphasis both on personal moral rectitude and on an ethic of comradely solidarity between socialists of all shades of opinion. Ideological correctness is not sufficient: it is important to be 'an upright man [un homme droit]', and 'at bottom, political history is explained much more by differences of character than by differences of ideas.' ${ }^{29}$ One might detect here the influence of Mauriac, who in his introduction to Guérin's 'Point de départ' had remarked on the dogmatism and sectarianism of French politics:

references to these notes will give just the sleeve number (in Roman numerals) within this folder.

${ }^{66}$ Guérin, Autobiographie, p. $22 \mathrm{I}$.

77 Coversheet attached to file, IISH, Box I, Folder 62; and Guérin, A la recherche d'un communisme libertaire (Paris: Spartacus, I984), p. 9.

78 See Berry, 'Metamorphosis'.

79 XVII: 'La ligne droite du socialisme'. 
The highest privilege of the novelist is that in these times of democracy, in which all of us live within the walls of a party, nobody reproaches him for his incursions between the lines and even as far as the enemy camp; there he learns that from one field to another, the motivations for human actions hardly vary. The novelist is exempt from the hate which the passion for the public good nowadays lights in the heart of the best of us $[\ldots] .{ }^{80}$

As a consequence, one of his main criticisms of the Russian bolsheviks, despite his admiration for Lenin and Trotsky, was that they seemed to him to be so driven by malice and hatred:

Beware of hatred, which defiles the soul. And if we fight what must be fought, let it be on the basis of Love, in the light of Love. [...] Too much hate. The cause is too beautiful, too irresistibly just, to be mixed up with so much hate. ${ }^{8 \mathrm{I}}$

The refusal of such dogmatism and sectarianism, and respect for the opinions of those with whom one disagrees, would certainly always be one of the characteristics of Guérin's political practice.

\section{The spiritual ideal}

Secondly, 'idealism', Guérin insisted, is an essential part of revolutionary politics, and much of his reading notes concerned not just the importance to socialism of idealism and morality, but also religion or spirituality. Reading Gandhi immediately after Sorel prompted him to comment on the superiority of the former in that Gandhism always held up 'a spiritual ideal at the end of its action' (although he did concede that “direct action' through nonviolence has not shown itself to be entirely effective'). ${ }^{82} \mathrm{He}$ also

\footnotetext{
8० La Revue hebodomadaire, 43 (24 October I925), p. 458.

${ }^{81}$ XIV: Notes on Pierre Chasles, La Vie de Lénine (I929). Capitalisation in the original.

${ }^{82}$ III: Notes on Le message révolutionnaire de Gandhi. When Gandhi visited Paris in I93I, Guérin wrote a very sympathetic report for the fortnightly syndicalist magazine La Révolution prolétarienne, and the following month published Gandhi's answers to a questionnaire Guérin had submitted to him through Romain Rolland, who hosted Gandhi's visit: 'Gandhi à Paris', December I93 I; 'Gandhi et la lutte de classes.
} 
read Unto This Last (I 862) by the English art critic and social reformer John Ruskin, a critique, based on a biblical parable, of the dominant economic ideas of the time, the reading of which in South Africa had prompted Gandhi to transform his way of life. Guérin also read Tolstoy's letters to Gandhi, as well as his The Kingdom of God is Within You (I 893) - a book which also had a powerful influence on Gandhi's evolution towards non-violence. ${ }^{83}$ Guérin directed some of his more impassioned criticisms at Trotsky for what seemed to him to be the casual acceptance of violence: 'Terrible. No, I refuse to believe that it will be in an immense pool of blood that we should build the edifice of the new social order. ${ }^{\prime 3}$

Guérin accepted that Tolstoy could be somewhat fashionable with the bourgeoisie, as it was unthreatening and seemed (to some at least) to require little action in comparison with Marxism; neverthless, 'there is in Tolstoy and in Gandhi, his spiritual son,' he insisted, 'a precious light which can illumine Marxism and extend it in Love [le prolonger dans l'Amour]. ${ }^{85}$ Guérin's notes also include the plan for a book entitled La Ligne Droite du Socialisme (literally The Straight Line of Socialism, although 'droit' also has ethical connotations), which includes a proposed chapter on 'Gandhism beyond Marxism'. ${ }^{86}$

Guérin continued to study Asian civilisations, reading amongst other works René Guénon's Introduction to the Study of the Hindu Doctrines and Emile Hovelacque's study of China. Of what he called 'the Orient', Guérin wrote:

Un entretien avec Gandhi et Romain Rolland', January I932. Available online at http://gallica.bnf.fr/.

83 Leo Tolstoi, 'The Kingdom Of God Is Within You.' Christianity Not As A Mystic Religion But As A New Theory Of Life (New York, I 894; translation by Constance Garnett). First published in French as Le Salut est en vous (Paris: Perrin, I893). See Gandhi, An Autobiography, p. I36.

${ }_{4}$ XV: Notes on Léon Trotsky, La Révolution défigurée (I929).

85 XIII: Notes on Luc Durtain, L'Autre Europe: Moscou et sa foi (1928). See also Marie-France Latronche, L'influence de Gandhi en France de I919 à nos jours (Paris: L'Harmattan, I999); and, for the argument in favour of seeing Gandhism as a form of non-violent anarchism, Manuel CerveraMarzal, 'Gandhi: de l'antilibéralisme à l'anarchisme non-violent', in Réfractions, 28 (May 20I2), pp. I 28-45.

86 XVII. 
Its spiritual civilisation can enrich us, bring us back to simplicity and to charity, which we have long forgotten. [...] All of humanity will one day drink from the same spiritual sources, in fraternity. ${ }^{87}$

The idea that a fulfilling human life cannot be achieved through an exclusive emphasis on merely material benefits or physical enjoyment recurs in Guérin's notes with some frequency, and was a belief expressed both with regard to some socialists' understanding of the 'good life' and to the developing consumer society under twentieth-century capitalism - as in this outburst provoked by a book on the contemporary USA: 'It is the final triumph of matter over spirit, the death of all inner life and of all spirituality. This is where we must listen to the lesson of the Orient, and reply to the businessman with Gandhi. ${ }^{98}$ (Despite his antiracism, Guérin was not immune to the essentialising exoticism characteristic of many European writers. ${ }^{89}$ ) Although Guérin notes explicitly his agreement with the Marxist view of the social role of religion as the opium of the people (in the sense that it taught the proletariat to be patient and simply content themselves with asking for alms, in Guérin's view), he was worried about Marxism's seemingly exclusive emphasis on the material advantages of socialism:

This is the terrible danger, the only danger of Marxism - Constantly to announce a material paradise is not to raise man up, but to cast him down even lower. We must regard sufficient material wellbeing as nothing more than the simple and necessary precondition of intellectual and spiritual development..$^{\circ}$

Guérin was of course not alone on the left in finding Marxism spiritually inadequate, and many of his comments echo the ideas of those such as Ernst Bloch for whom Marxism was 'insufficiently utopian'. ${ }^{\text {I }}$ Nor is this a question which seems to have concerned

${ }_{87}$ IX: Notes on Emile Hovelacque, La Chine (I920).

${ }_{88} \mathrm{X}$ : Notes on Octave Homberg, L'Impérialisme américain (1929).

89 See Kate Marsh, 'Gandhi and le gandhisme: Writing Indian Decolonisation and the Appropriation of Gandhi I9I9-48', Modern \& Contemporary France, I4: I (2006), 33-47.

$9 \circ \mathrm{XX}$ : Notes on É. Vandervelde, Jaurès (1929). Emphases in the original.

91 Leszek Kolakowski, Main Currents of Marxism: Its Origin, Growth, and Dissolution, vol. 3: The Breakdown (Oxford: Clarendon Press, I978), 
Guérin only in his 20s. In I945, he wrote a congratulatory letter to the Italian novelist Ignazio Silone after reading The Seed Beneath the Snow:

I do not know how to find the words to describe to you the profound impression the novel has made on me. [...] What struck me above all is that your book is on the borderline between Catholic spiritualism and Marxist materialism. I do not believe anybody else combines in himself these two conceptions of the world..$^{92}$

Indeed Guérin thought so highly of the novel that in I96I he adapted it for the stage. ${ }^{93}$

The folder of Guérin's reading notes also contains a cutting from the review Monde about Hendrik de Man, a social psychologist at the University of Frankfurt - where he was a colleague of Karl Mannheim and Max Horkheimer - and a leading figure in the Belgian Workers' Party. ${ }^{94}$ De Man had first come to prominence just a few years before with the publication in 1926 of Zur Psychologie des Sozialismus [On the Psychology of Socialism], an 'intensive critique of the stultifying legacy of Second International determinism'.95 De Man's ideas for a positive alternative to

p. 423. I know of no evidence that Guérin knew of Bloch's work (although he did read German), but most of Bloch's main ideas were already developed in the I920s: Geist der Utopie [Spirit of Utopia], which argued that humans are utopian subjects, appeared in I918, and Durch die Wüste [Through the Desert], which attacked the utilitarianism and nihilism of modern bourgeois civilisation, in 1923 .

${ }^{92}$ Letter of 23 October I945, BDIC Fº́s Rés.688/Io/I. See Stanislao G. Pugliese, 'Wrestling with Two Angels: Communism and Christianity in the Work of Ignazio Silone', in New Directions in Italian and ItalianAmerican History, ed. by Ernest Ialongo and William M. Adams (New York: Calandra Italian American Institute CUNY, 20I3), pp. 50-64; and Tom Moylan, 'Anticipatory Fiction: Bread and Wine and Liberation Theology', Modern Fiction Studies, 35: I (Spring I989), I03-I 7.

93 The adaptation was published as Le Grain sous la neige (Paris: Del Duca/ Editions mondiales, I96I).

94 Monde was created by the writer, pacifist and communist Henri Barbusse in 1928.

95 Gerd-Rainer Horn, 'From 'Radical' to 'Realistic': Hendrik de Man and the International Plan Conferences at Pontigny and Geneva, I934-I937', Contemporary European History, IO: 2 (July 200I), 239-65 (p. 243). 
orthodox Marxism, with a view to reinvigorating the socialist movement, were developed subsequently. He notably argued for a redefinition of 'interests' and 'needs' in order to embrace religious and ethical ideas, and emphasised the disinterested, ethical impetus in socialism. His main criticism of Marxism was that it was overly deterministic, neglecting morality, psychology and the human will, and that it was too disdainful of the power of religion as a provider of a set of moral values. De Man published Au-delà $d u$ marxisme [Beyond Marxism] in 1927, and the following year was one of the founders of a new movement whose focus was the reconciliation of Western religious traditions with socialism. ${ }^{96}$ De Man asserted that there was 'a common ethical substructure to all universalistic religious systems' and that these 'would be translated into secular realization only through the socialist program.' ${ }^{97}$ He also argued that the socialist movement was suffused with 'eschatological yearning'. ${ }^{8}$

Thirdly, Guérin seems to have been drawn both to the total personal commitment implied by the bolshevik idea of the 'professional revolutionary' and to Tolstoy's and Gandhi's ideas on the priority to be attached to moral self-improvement. On reading a biography of Lenin, he noted: 'A man who claims to be a socialist no longer has the right to devote a part of his intelligence to sterile intellectual exercises.' 99 And in his notes on a study of Trotsky, having first invoked Gandhism, he commented:

Before replacing the bourgeoisie, first show yourselves to be superior to them [...] by virtue of your morality: abstain from drunkenness; accept the rigourous discipline of the trade union; push aside exclusively material appetites; love your neighbour - and you will be more worthy of power than the bourgeoisie. ${ }^{\text {100 }}$

\footnotetext{
${ }^{6}$ Peter Dodge, Beyond Marxism: The Faith and Works of Hendrik de Man (The Hague: Martinus Nijhoff, I966), p. 67.

97 Dodge, Beyond Marxism, p. I08.

$9^{8}$ Gentile, Politics as Religion, p. 7.

99 XIV: Notes on Pierre Chasles, La Vie de Lénine (I929).

ro XIII: Notes on Pierre Fervacque [pseud. of Rémy Roure], La Vie orgueilleuse de Trotski (Paris: Fasquelle, I929).
} 
Bourgeois socialists, he wrote, can never understand working-class realities unless they are completely 'expropriated', cut off from their roots and forced to live as workers: 'This rôle must be really lived'. ${ }^{\text {ror }}$ There are perhaps certain parallels here between Guérin's subsequent decision to do precisely that (of which more below) and the social-Catholic 'worker-priests' of the I940s-50s, as well as the students of the puritanical maoist Union des Jeunesses Communistes (Marxistes-Léninistes) going to work in the factories in the I960s. ${ }^{102}$

\section{Metamorphosis}

In his notes on Sorel, Guérin commented that 'it is not through ideology that I came to socialism, but through the body and through the heart', and in his autobiographies and interviews, Guérin was keen to emphasize the visceral nature of his political commitment, derived from his direct personal knowledge of the bourgeoisie and of the colonial system, but also from his relationships with working-class men:

Although founded on very wide reading, the metamorphosis which led me to socialism was not objective, on an intellectual level. Rather it was subjective, physical, stemming from the senses and the heart. [...] I had sought camaraderie. It was that which I hoped to find a hundredfold in socialism. ${ }^{103}$

He felt at that time as if the 'metamorphosis' he was undergoing was a kind of sublimation of his own sexuality in his new aim in life:

I resolved to employ my particular form of eroticism, thus far uncontrolled, wasted and more or less asocial, and to subordinate it to the highest ends: the liberation of all, which would at the same time be my own liberation. ${ }^{\mathrm{I}}{ }^{4}$

го XXII/a: Notes on Hyacinthe Dubreuil, La République industrielle (Paris: Bibliothèque d'éducation, n.d.).

1о2 See Christophe Bourseiller, Les maö̈stes. La folle histoire des gardes rouges français (Paris: Points, 2008), pp. 109-26.

I03 Guérin, Autobiographie, p. 2 I 8.

104 Guérin, Autobiographie, p. 2 I9. 
Back in Paris in April I930, Guérin's attempts at explanation did little to soothe his parents' alarm at his decision, and faced with their incomprehension and disapproval, he cut his economic ties with his family. Having found work as a proof-reader, he moved out of the family home and found a room in the working-class quarter of Belleville. ${ }^{105}$ Both geographically and sociologically, this was a Paris which had not been part of his world until now, beyond going to work in La Chapelle in I925. Guérin liked it there: 'It was the happiest period of my life, getting to know this proletarian milieu. ${ }^{\text {'06 }}$ The other inhabitants of the building, mostly young construction workers, were friendly and sociable and became a kind of substitute family. His small room was (to use Guérin's words) like a monk's cell in its bareness. As a police surveillance report on him put it:

He occupies a modest and uncomfortable room. [...] The subject is described as a mystic. He strives to live modestly in accordance with the meagre resources he earns from his work as a manual worker and journalist. He nevertheless regularly visits his parents, 22 Boulevard Saint-Michel, who naturally deplore the political attitude of their son. ${ }^{\text {107 }}$

As Guérin himself commented, 'I looked for myself, I more or less found myself', and an essential part of that was abandoning the class from which he sprang:

ros See Patrice Spadoni, 'Daniel Guérin - 5 rue Lesage', in Un Paris révolutionnaire, ed. by Claire Auzias (Paris: L'esprit frappeur, 200I), pp. 366-8.

${ }^{106}$ Interview in television documentary, Daniel Guérin, dir. Jean-José Marsand, questionnaire and interview by Pierre André Boutang (Broadcast on FR 3, 4 \& I I September I989, série Archives du XXe Siècle; film made in I985); interview material re-used in Laurent Muhleisen \& Patrice Spadoni, Daniel Guérin, I904-1988: Combats dans le siècle (Productions Imagora, n.d.).

${ }_{107}$ Archives Nationales, Centre des archives contemporaines (CAC), Versement coté I 9940448, Fichier central de la Direction générale de la Sûreté nationale du Ministère de l'Intérieur, Box 450, file 38 I45; quoted in Antonio de Francesco, 'Daniel Guérin et Georges Lefebvre, une rencontre improbable', La Révolution française (Cahiers de l'Insitut d'histoire de la Révolution française), http://lrf.revues.org/I 62 
I irrevocably abandoned one familial clan [...] to join another, which was infinitely more vast since it embraced the wretched of the earth. It is more exalting than the first, for it counts within its ranks truth and justice, and more powerful, since it has number in its favour. ${ }^{\text {I08 }}$

This was undoubtedly a pivotal moment in Guérin's life, and is strongly reminiscent of the moral crisis which led Tolstoy in the I 870 s to renounce all his earlier literary works, and of Gandhi's decision to adopt what he called a 'religion of service', feeling that 'God could be realized only through service.' ${ }^{\circ 09}$ Guérin, vowing to devote his life to 'the struggle for the abolition of the social and colonial scandal', similarly renounced all the 'superfluous' pastimes of his privileged youth, burning his unpublished fictional writings and consigning to silence his published poems and novels, ashamed of their very existence. ${ }^{\text {I1 }}$

\section{Mana}

Others' commentaries on Guérin's early years, as well as his own, have tended to be framed either in terms of the break with his own class and his quest for 'the great family of fraternal camaraderie and shared struggle', 'the camaraderie of community'; ${ }^{\text {III }}$ or in terms of the problems he experienced coming to terms with his sexuality; ${ }^{\mathrm{II} 2}$ or in terms of his quest to 'reunify' his self, his identity, as both revolutionary and homosexual. It seems to me that another (complementary) perspective is possible. On such a reading, spirituality acquires a more important - perhaps even central - rôle in determining Guérin's life decisions and, indeed,

${ }^{108}$ Guérin, Autobiographie, p. 229.

109 Gandhi, An Autobiography, p. I 55.

по Guérin, Autobiographie, p. 227. On Guérin's social and political engagements from I930 onwards, see David Berry, "Un contradicteur permanent': The ideological and political itinerary of Daniel Guérin', in After the Deluge: New Perspectives on the Intellectual and Cultural History of Postwar France, ed. by Julian Bourg (Lanham, MD: Lexington Books, 2004), pp. I49-74.

II Guérin, Eux et Lui, pp. 7 \& 8.

II2 Guérin, 'Commentaires très libres sur les Mémoires d'un jeune homme excentrique', Text of a talk given by Daniel Guérin on I7 February I 965. 
his everyday conduct, and particularly at this crucial moment in his life. It is doubtless necessary to distinguish between religion and the admittedly rather ambiguous term spirituality. We have already seen that Guérin rejected the Church and Christian dogma, and his history of the French Revolution is certainly sympathetic towards the revolutionaries' policy of 'dechristianisation'. ${ }^{\mathrm{II} 3}$ In I968, he insisted on the need to fight the 'obscurantist fanaticism' of the Catholic Church. ${ }^{114}$ And in the raw confessional text Eux et Lui (first published in I959), he wrote (in the third person) of his lack of religious belief:

Neither god nor the devil cohabited within him, fighting over his soul. The absence of god did not represent, in him, an obsession with god, and hell was the least of his worries. A believer [...] would have perceived in him the ravages caused by the absence of god. But he ignored such self-interested suggestions and he managed perfectly well without god.

So clearly Guérin had moved beyond his youthful agonising over religion in the sense of belief in a supernatural deity and church doctrine, yet he went on: 'For him the cosmos, with which he believed he communicated and which filled him with its mana, took the place of god.' ${ }^{\text {'I5 }}$ How one should interpret this remark is unclear. 'Mana' is a concept drawn from the cultures of the Pacific islands (Polynesia, Melanesia, Micronesia) and has a number of meanings which depend on context, but tend to be associated with sacred or spiritual authority, power or energy. ${ }^{\text {I16 }}$ Perhaps Guérin is suggesting some kind of numinous experience of the sacred which, in the words of the theologian Rudolf Otto, produced an irrational energy which...

${ }^{113}$ Guérin, La lutte de classes sous la Pemière République, I793-I797 (Paris: Gallimard, I946; revised edition I968), 2 vols.

${ }^{114}$ 'De la répression sexuelle à la Révolution', from Le Point, Brussels, December 1968, in Guérin, Homosexualité et révolution (Paris: Le Vent du ch'min, I983), p. 34.

is Guérin, Eux et lui (Lille: Gai Kitsch Camp, 2000), p. I6.

${ }_{116}$ Tony Swain \& Garry Trompf, The Religions of Oceania (London \& New York: Routledge, I995). 
engages man's sentiments, drives him to 'industrious fervour' and fills him with a boundless dynamic tension both in terms of asceticism and zealousness against the world and the flesh, and in terms of heroic behaviour by which the inner excitement erupts into the external world. ${ }^{117}$

Or perhaps, rather, it makes sense to see similarities with Bloch's utopian spirit - Guérin certainly had strong chiliastic tendencies, as seen, for instance, in Eux et Lui, when he cites Trotsky's I940 Testament:

[W] hatever may be the circumstances of my death I shall die with unshaken faith in the communist future. This faith in man and in his future gives me even now such power of resistance as cannot be given by any religion. ${ }^{118}$

Or perhaps it means little more than an 'emotional attitude', to use Orwell's words? In a later autobiography, he employed the concept of mana again when discussing the fact that many people seemed unable to reconcile Guérin the anticolonialist and revolutionary socialist with Guérin the campaigner for (homo) sexual liberation:

Personally, I believe that one and the same vital energy or, to use the Melanesian term, one and the same mana, has been the driving force in my political as well as my carnal life. ${ }^{\text {I9 }}$

Similarly, he once commented in an interview that 'the driving force of my life has been love' ${ }^{\text {I20 }}$ - which brings us back to Gandhi. Reading of Guérin's determination to start his life afresh in I930, and recalling the way in which he earlier described his 'discovery'

${ }^{117}$ Otto, The Idea of the Holy: An Inquiry into the Non-rational Factor in the Idea of the Divine and Its Relation to the Rational (London \& New York, I9I7), quoted in Gentile, Politics as Religion, p. Io.

II8 Guérin, Eux et lui, p. 94. Translation from Leon Trotsky, 'Testament' (3 March I940), http://www.marxist.com/testament-of-leon-trotsky.htm

II Guérin, Le feu du sang. Autobiographie politique et charnelle (Paris: Grasset \& Fasquelle, I977), p. 7. See David Berry, "Workers of the World, Embrace!' Daniel Guérin, the Labour Movement and Hommosexuality', Left History, 9: 2 (Spring/Summer 2004), I I-43.

ז20 'Géographie passionnelle d'une époque. Entretien avec Daniel Guérin', Débattre Io (2000), 5-Io. 
of the working-class quarters of Paris as 'restarting [his] life from zero', one cannot help but be reminded of the closing lines of one of the many books he read on board the Bangkok, one which seems to have had a more profound impact than most, namely Gandhi's autobiography: 'I must reduce myself to zero. So long as a man does not of his own free will put himself among his fellow creatures, there is no salvation for him.' ${ }^{\text {I2I }}$

\section{Conclusion}

It seems clear that Guérin's commitment to ending the 'social and colonial scandal' was motivated by moral outrage and by a profound sense of guilt at his own privileges as a member of the grande bourgeoisie and as a white man. He sought redemption through a Gandhian 'religion of service', putting himself at the service of the Revolution (with a capital R) in order to help the oppressed and exploited achieve liberation. Love (with a capital L) - 'charity', 'the heart', 'fraternity', 'camaraderie' - was central to his thinking and to his responses to others' suffering; for him it was constitutive of what it is to be human and therefore enabled self-realisation through 'merging with the people' (Gandhi's 'putting himself among his fellow creatures'). Although he doubtless exaggerates the extent to which his decision to devote his life to social revolution was 'visceral' (rather being prompted by a more rational decision based on his extensive studies), it was certainly rooted in his personal experiences and relationships, and in his compassionate, empathetic responses to them - 'in the heart', to use his words. His deep dissatisfaction with the spiritual vacuousness both of capitalist society and of his own nihilistic indulgence in physical pleasures led him to seek 'sure values', meaning and 'spiritual nourishment' elsewhere. Guérin's political commitment might thus be seen as an instance of the kind of religious experience described by Durkheim as producing 'the transport of the individual beyond himself.' ${ }^{122}$ In such a view, society becomes the divinity.

I21 Gandhi, An Autobiography, p. 454.

I22 Emile Durkheim, The Elementary Forms of Religious Life ( I930), quoted in Gentile, p. 8. 
Does it make sense to use the much debated concepts of 'political religion' or 'secular religion' with regard to Guérin? The more general term 'secular religion' has been used of ideologies or ideals which replaced traditional, metaphysical religious beliefs with humanist ideas such as humanity or society. The notion of sacralisation the creation by such beliefs of 'an aura of sacredness around an entity belonging to this world' ${ }^{\mathrm{I}_{23}}$ - may be useful in helping us understand Guérin's commitment to the cause. De Man wrote of the idea of the Revolution which 'so powerfully evokes emotions that recall the eschatological visions of the Apocalypse, the end of the world, the Last Judgement, the Kingdom of God, etc.' ${ }^{\text {I24 }}$ And Guérin's use of a quotation from Trotsky's 'Testament' suggests that Guérin's relationship to his revolutionary socialist politics, the meaning and purpose with which it invested his life, his faith in the ultimate inevitability of the Revolution and the devotion it aroused in him could indeed be seen as a form of 'sacralisation' characteristic of a 'political religion'. As religious historian Giovanni Filoramo put it:

[T] he process of sacralization is triggered when individuals and groups of people confer an absolute value on objects and symbols in order to make sense of their individual or collective existence. ${ }^{125}$

Guérin, in common with many of his generation, did have a very nineteenth-century belief in the inevitability of the Revolution, a faith which can be seen as a form of 'social transcendance' of the kind identified by Salvador Giner. ${ }^{\mathrm{I2} 6}$

But the definition and usefulness of the concepts of secular or political religion are still debated, and a particular problem here is that 'political religion' tended for a long time to be used principally in analyses of fascism, nazism or bolshevism, and were thus assumed to involve repressive and demagogic techniques designed to bolster totalitarian systems - what Gentile calls the 'crowd manipulation interpretation of religion'. Guérin would himself devote a whole chapter of his 1936 classic Fascism and Big Business

\footnotetext{
${ }^{123}$ Gentile, Politics as Religion, p. I.

I24 Quoted in Gentile, p. 7.

${ }^{25}$ Quoted in Gentile, p. I4.

I26 Salvador Giner, quoted in Gentile, Politics as Religion, p. I4.
} 
to fascist 'mysticism' and insisted that fascism was a religion. But Guérin also gave attention to an analysis of the psychological mechanisms at play in inter-war Europe which meant that so many people were receptive, thus enabling fascism to become a quasi-religious mass movement based on faith, belief and emotional fervour - in other words Guérin employed a 'fideistic' interpretation, as well as a 'crowd manipulation' interpretation. Clearly, the latter kind of use of the concepts of political or secular religion, with their connotations of demagogy, irrationalism and fanaticism - whether we are thinking of the inter-war years or the Cold War era - are inappropriate in Guérin's case: he was too rational, too well informed, too committed to open and honest debate among comrades, too scornful of dogma and sectarianism. Indeed, as we have seen, he quite explicitly condemned the way in which Marx and Lenin had, in his eyes, been 'sacralised' (his term) and come to be regarded as infallible prophets.

And yet I think we can say that Guérin - as Mauriac perceptively pointed out when he compared Guérin to Psichari, emphasising the former's apparent need to 'belong to a religious order' - did have strong fideistic tendencies, if we understand by that 'the need to submit oneself to a divine, political or social faith' in Le Bon's words. ${ }^{127}$ Guérin was an adherent of what Gentile calls a 'religion of humanity' ${ }^{\mathrm{I} 28}$, in the sense that his socialism provided a morality, a meaning and direction, and hope for a better world.

\section{References}

Gilles Barbedette and Michel Carassou (ed.), Paris Gay I925 (Paris: Presses de la Renaissance, I98I).

Jean-Luc Barré, François Mauriac: Biographie intime, vol.ı: I885-I940 (Paris: Fayard, 2009).

David Berry, “Workers of the World, Embrace!' Daniel Guérin, the Labour Movement and Hommosexuality', Left History, 9: 2 (Spring/Summer 2004), I I-43.

${ }^{127}$ Quoted in Gentile, Politics as Religion, p. 6.

I28 Gentile, Politics as Religion, p. xvi. 
- 'Un contradicteur permanent': The ideological and political itinerary of Daniel Guérin', in After the Deluge: New Perspectives on the Intellectual and Cultural History of Postwar France, ed. by Julian Bourg (Lanham, MD: Lexington Books, 2004), pp. I49-74.

—_ 'Metamorphosis: The Making of Daniel Guérin, I904-I930', Modern \& Contemporary France vol. 22, no. 3 (August 20I4), $32 \mathrm{I}-42$.

, 'From son of the bourgeoisie to servant of the Revolution: The roots of Daniel Guérin's revolutionary socialism', Moving the Social - Journal of Social History and the History of Social Movements vol. 5I (20I4), pp. 283-3II.

— , 'The Search for a Libertarian Communism: Daniel Guérin and the 'synthesis' of Marxism and Anarchism', in Libertarian Socialism: Politics in Black and Red ed. by Alex Prichard, Ruth Kinna, Saku Pinta \& David Berry (Oakland, CA: PM Press, 2017), pp. I87-209.

Yves Blondeau, Le Syndicat des correcteurs de Paris et de la région parisienne, I88I-I973 (Paris: Syndicat des correcteurs, I973).

Christophe Bourseiller, Les maoïstes. La folle histoire des gardes rouges français (Paris: Points, 2008).

Manuel Cervera-Marzal, 'Gandhi: de l'antilibéralisme à l'anarchisme non-violent', in Réfractions, 28 (May 20I2), pp. I28-45.

Christian Chabanis, Dieu existe-t-il? Non (Paris: Fayard, I973).

Peter Dodge, Beyond Marxism: The Faith and Works of Hendrik de Man (The Hague: Martinus Nijhoff, I966).

Peter France (ed.), The New Oxford Companion to Literature in French (Oxford: Oxford University Press: 1995).

Antonio de Francesco, 'Daniel Guérin et Georges Lefebvre, une rencontre improbable', La Révolution française (Cahiers de l'Insitut d'histoire de la Révolution française), http://lrf.revues.org/I62.

Mohandas Gandhi, An Autobiography. The Story of my Experiments with Truth (London: Penguin, 2007). First published I927-29.

Emilio Gentile, Politics as Religion (Woodstock: Princeton University Press, 2006). 
R. Gibson, 'The First World War and the Literary Consciousness', in French Literature and its Background, ed. by John Cruickshank (Oxford: Oxford University Press, I970), vol. 6, pp. 56-72.

Mary Jean Green, 'Visions of Death and Dissolution', in A New History of French Literature, ed. by Denis Hollier (Cambridge MA: Harvard University Press, I989), pp. 850-5.

Daniel Guérin, Le Livre de la dix-huitième année (Paris: Albin Michel, I922).

—-, 'Point de départ', La Revue hebdomadaire, 43 (24 October I925), 457-68.

—, L'Enchantement du Vendredi Saint (Paris: Albin Michel, I925).

—, La Vie selon la chair (Paris: Albin Michel, I929).

- Fascisme et grand capital (Paris: Gallimard, I ${ }^{\text {st }}$ ed. I936); translated by Frances and Mason Merrill as Fascism and Big Business (New York: Pioneer Press, I ${ }^{\text {st }}$ ed. I939), introduced by Dwight Macdonald.

—_, La Lutte de classes sous la Première République, I793-I797 (Paris: Gallimard, I946; revised edition I968), 2 vols.

- Shakespeare et Gide en correctionnelle? Essai (Paris: Editions du Scorpion, I959).

—., L'Anarchisme, de la doctrine à la pratique (Paris: Gallimard, $\mathrm{I}^{\text {st }}$ ed. I965); translated by Mary Klopper as Anarchism: From Theory to Practice (New York \& London: Monthly Review Press, I970); Introduction by Noam Chomsky.

—_ Ni dieu ni maître, anthologie de l'anarchisme (Lausanne: La Cité-Lausanne, $\mathrm{I}^{\text {st }}$ ed. I965); translated by Paul Sharkey as No Gods, No Masters: An Anthology of Anarchism (Edinburgh: AK Press, I998), 2 vols.

—_, Autobiographie de jeunesse. D'une dissidence sexuelle au socialisme (Paris: Belfond, I972).

—, Ci-git le colonialisme (Paris: Mouton la Haye, I973).

- Le feu du sang. Autobiographie politique et charnelle (Paris: Grasset \& Fasquelle, 1977). 
—, Homosexualité et révolution (Paris: Le Vent du ch'min, 1983).

—, Eux et lui (Lille: Gai Kitsch Camp, 2000).

—, 'Géographie passionnelle d'une époque. Entretien avec Daniel Guérin’, Débattre Io (2000), 5-10.

F. W. J. Hemmings, The Russian Novel in France, I 884-I9 I4 (Oxford University Press, I950).

D. Bruce Hindmarsh, The Evangelical Conversion Narrative: Spiritual Autobiography in Early Modern England (Oxford: OUP, 2007).

Gerd-Rainer Horn, 'From 'Radical' to 'Realistic': Hendrik de Man and the International Plan Conferences at Pontigny and Geneva, I934-I937', Contemporary European History, Io: 2 (July 200I), $239-65$.

Janet R. Horne, A Social Laboratory for Modern France: The Musée Social and the Rise of the Welfare State (Durham, NC: Duke University Press, 2002).

Leszek Kolakowski, Main Currents of Marxism: Its Origin, Growth, and Dissolution, vol. 3: The Breakdown (Oxford: Clarendon Press, I978).

Marie-France Latronche, L'influence de Gandhi en France de I9 I9 à nos jours (Paris: L'Harmattan, I999).

Pierre Loti, Un Pèlerin d'Angkor (Paris: Calmann-Lévy, I9 I 2).

Jean-José Marsand (dir.), Daniel Guérin, TV documentary (Broadcast on $\mathrm{FR}_{3,4}$ \& I I September I989, série Archives du XXe Siècle; film made in 1985 ).

Kate Marsh, 'Gandhi and le gandhisme: Writing Indian Decolonisation and the Appropriation of Gandhi I919-48', Modern \& Contemporary France, I4: I (2006), 33-47.

François Mauriac, Nouvelles lettres d'une vie (1906-70), ed. by Caroline Mauriac (Paris: Bernard Grasset, I989).

Marie \& François Mayoux, Instituteurs pacifistes et syndicalistes. Mémoires de F. Mayoux (Chamalières: Editions Canope, I992).

Tom Moylan, 'Anticipatory Fiction: Bread and Wine and Liberation Theology', Modern Fiction Studies, 35: I (Spring I989), I03-I7. 
Laurent Muhleisen \& Patrice Spadoni (dir.), Daniel Guérin, I904-1988: Combats dans le siècle (Productions Imagora, n.d.).

Christopher John Murray (ed.), Encylopedia of Modern French Thought (New York \& London: Fitzroy Dearborn, 2004).

Pierre Nora (ed.), Realms of Memory. The Construction of the French Past (New York: Columbia University Press, 1996).

George Orwell, 'Why I Write' (I946), in The Collected Essays, Journalism and Letters of George Orwell, vol. I - An Age Like This I945-I950 (London: Penguin, I970); also available at: http:// orwell.ru/library/essays/wiw/english/e_wiw.

Blaise Pascal, Pensées (New York: E. P. Dutton \& Co., Inc. 1958).

Pierre-Joseph Proudhon, Système des contradictions économiques. Philosophie de la misère (Paris: Garnier Frères, I 850 ).

Stanislao G. Pugliese, 'Wrestling with Two Angels: Communism and Christianity in the Work of Ignazio Silone', in New Directions in Italian and Italian-American History, ed. by Ernest Ialongo and William M. Adams (New York: Calandra Italian American Institute CUNY, 20I3), pp. 50-64.

Ignazio Silone, Le Grain sous la neige (Paris: Del Duca/Editions mondiales, I96I), adapted by D. Guérin.

Jean-François Sirinelli, Génération intellectuelle: khagneux et normaliens dans l'entre-deux-guerres (Paris: Fayard, I988).

Patrice Spadoni, 'Daniel Guérin - 5 rue Lesage', in Un Paris révolutionnaire, ed. by Claire Auzias (Paris: L'esprit frappeur, 200I), pp. 366-8.

Tony Swain \& Garry Trompf, The Religions of Oceania (London \& New York: Routledge, I995).

Leo Tolstoi, 'The Kingdom Of God Is Within You.' Christianity Not As A Mystic Religion But As A New Theory Of Life (New York, I 894; translation by Constance Garnett). First published in French as Le Salut est en vous (Paris: Perrin, I893).

Paul Valéry, 'La Crise de l'esprit', first published in Variété (Paris: Gallimard, I924), http://wikilivres.ca/wiki/La_Crise_de_1\%E2\% $80 \%$ 99esprit. 
188 Essays in Anarchism and Religion: Volume III

Todd Weir, 'Between Colonial Violence and Socialist Worldview: The Conversions of Ernst Däumig', German History 28: 2 (2010), I 43-66.

Robert Wohl, The Generation of I9I4 (London: Weidenfeld and Nicolson, I980). 